

\section{Daftar Isi (Table of Content) Journal of Government
Civil Society}

\begin{tabular}{|c|c|}
\hline \multirow{3}{*}{$146-163$} & $\begin{array}{l}\text { New Public Management (New Public Comparison Meta-Analysis } \\
\text { Developed and Developing Country Policies) }\end{array}$ \\
\hline & Dyah Mutiarin², Misran $^{1}$ \\
\hline & $\begin{array}{l}\text { ( }{ }^{1} \text { Department of Government Affairs and Administration, Universitas Muhammadiyah } \\
\text { Yogyakarta, Indonesia) } \\
\text { (' Jusuf Kalla School of Government, Universitas Muhammadiyah Yogyakarta, Indonesia) }\end{array}$ \\
\hline \multirow{3}{*}{$164-183$} & $\begin{array}{l}\text { Policy Networks: Actors, Interests, and Power Relations in the Jakarta } \\
\text { Reclamation Project }\end{array}$ \\
\hline & Rizki Hegia Sampurna1,2, Chih-Chieh Chou ${ }^{1}$ \\
\hline & $\begin{array}{l}\text { (' Department of Political Science, National Cheng Kung University (NCKU), Taiwan) } \\
\text { ( }{ }^{2} \text { Department of Public Administration, Universitas Muhammadiyah Sukabumi (UMMI), } \\
\text { Indonesia) }\end{array}$ \\
\hline \multirow{3}{*}{$184-197$} & $\begin{array}{l}\text { National Insights and Youth Political Attitudes in Rural Lampung Against } \\
\text { Negative Campaign }\end{array}$ \\
\hline & Hertanto $^{1}$, Handi Mulyaningsih², Asep Nurjaman ${ }^{3}$ \\
\hline & $\begin{array}{l}\left({ }^{1} \text { Departement of Government Science, Universitas Lampung, Indonesia) }\right. \\
\left({ }^{2} \text { Departement of Sociology, Universitas Lampung, Indonesia) }\right. \\
\left({ }^{3} \text { Departement of Government Science, Universitas Muhammadiyah Malang, Indonesia) }\right.\end{array}$ \\
\hline \multirow{3}{*}{$198-213$} & $\begin{array}{l}\text { Ethnic Identity and Local Politics: Study on Regional Head Election in } \\
\text { Merauke Regency } 2020\end{array}$ \\
\hline & Misran$^{1}$, Wahdania Sardi ${ }^{1}, Z^{2}$ uly Qodir ${ }^{1}$ \\
\hline & $\begin{array}{l}\left({ }^{1} \text { Department of Government Affairs and Administration, Jusuf Kalla School of Government, }\right. \\
\text { Universitas Muhammadiyah Yogyakarta, Indonesia) }\end{array}$ \\
\hline \multirow{3}{*}{$214-236$} & $\begin{array}{l}\text { Stakeholder Collaboration Model for Ecotourism Development: A Case } \\
\text { Study from Batu City, East Java Province }\end{array}$ \\
\hline & $\begin{array}{l}\text { I Gede Eko Putra Sri Sentanu' }{ }^{1} \text {, Ardian Prabowo', Klara Kumalasari'1, } \\
\text { Aulia Puspaning Galih', Rendra Eko Wismanu }{ }^{1}\end{array}$ \\
\hline & (' Departement of Public Administration, Universitas Brawijaya, Indonesia) \\
\hline
\end{tabular}


Farmers Social Movement Studies: A Systematic Literature Review for A Conceptual Model

$237-262 \quad$ Wahyudi $^{1}$

(' Department of Sociology, Universitas Muhammadiyah Malang, Indonesia)

Factors Affecting Trust in E-Government

Ulung Pribadi' ${ }^{1}$, Muhammad Iqbal ${ }^{2}$, Fittia Restiane ${ }^{3}$

263 - 276 (1 Post-Graduate Program Universitas Muhammadiyah Yogyakarta, Indonesia)

( ${ }^{2}$ Department of Political Science National Cheng Kung University, Taiwan)

$\left({ }^{3}\right.$ Department of Government Affairs and Administration Universitas Muhammadiyah Yogyakarta, Indonesia) 


\title{
Factors Affecting Trust in E-Government
}

\author{
Ulung Pribadi ${ }^{1 *}$, Muhammad Iqbal ${ }^{2}$, Fittia Restiane ${ }^{3}$ \\ ${ }^{1}$ Post-Graduate Program Universitas Muhammadiyah Yogyakarta, Indonesia \\ ${ }^{2}$ Department of Political Science National Cheng Kung University, Taiwan \\ ${ }^{3}$ Department of Government Affairs and Administration Universitas Muhammadiyah Yogyakarta, \\ Indonesia \\ * Email Correcpondence: ulungpribadi@umy.ac.id
}

\begin{abstract}
This study examined perceived usefulness, information quality, and privacy and security to predict trust in egovernment. This study used a survey data collection method and a random sampling technique with 100 residents who visit the local government's public services website as respondents. A Likert scale was used to create the questionnaires. SEM-PLS looked at the data to see if it was valid and reliable, as well as test hypothesis and regression. This study found that perceived usefulness, information quality, and privacy and security had a positive and significant effect on trust in e-government with p-values of 0.000, 0.001 and 0.000, respectively. The influence of the three independent variables towards the dependent variable was moderate ( $R$-square $=$ 0.494). Finally, the limitations and implications of these findings are examined.
\end{abstract}

Keywords: Trust in e-government, perceived usefulness, information quality, privacy and security, Indonesia

\begin{abstract}
ABSTRAK
Studi ini menguji manfaat yang dirasakan, kualitas informasi, dan privasi dan keamanan untuk memprediksi kepercayaan pada e-government. Penelitian ini menggunakan metode pengumpulan data survei dan teknik random sampling dengan 100 orang warga yang mengunjungi website layanan publik pemerintah daerah sebagai responden. Sebuah skala Likert digunakan untuk membuat kuesioner. SEM-PLS melihat data untuk melihat apakah itu valid dan reliabel, serta menguji hipotesis dan regresi. Studi ini menemukan bahwa persepsi manfaat, kualitas informasi, dan privasi dan keamanan memiliki pengaruh positif dan signifikan terhadap kepercayaan pada e-government dengan nilai p masing-masing $0,000,0,001$ dan 0,000 . Pengaruh ketiga variabel bebas terhadap variabel terikat adalah sedang (R-square $=0,494)$. Akhirnya, keterbatasan dan implikasi dari temuan ini diperiksa.
\end{abstract}

Kata Kunci: Kepercayaan pada e-government, manfaat yang dirasakan, kualitas informasi, privasi dan keamanan, Indonesia.

\section{INTRODUCTION}

Governments of many countries, both central and local governments, have used egovernment recently in order to improve access and basic services for their citizens. The implementation of various types of e-government is a means of cooperation between the government and its stakeholders to achieve effectiveness, efficiency, transparency, economic growth, public participation, and sustainable development (Panthee \& Sharma, 2019; Liywalii \& Tembo, 2019; Shkarlet et al., 2020; Mosud \& Govender, 2020; Glyptis et

Citation : Pribadi, U., Iqbal, M., \& Restiane, F. (2021). Factors Affecting Trust in E-Government. Journal of Government and Civil Society, 5(2), 263-276. https:/ / doi.org/DOI: 10.31000/jgcs.v5i2.4848 
al., 2020; Dias, 2020; Ingrams et al., 2020; Horák et al., 2021; Nofal et al., 2021; Kamarudin et al., 2021).

Trust in e-government is the key to the successful implementation of digital technology in the government. Therefore, many scholars have conducted studies regarding trust in e-government (Alzahrani et al., 2017; Bayaga et al., 2020). Ejdys et al. evaluated trust in e-government in Poland in the case of the electronic filing of tax returns (Ejdys et al., 2019). Aljazzaf evaluated the people intention to trust e-government in Kuwait in using the government's web to convey data and administrations (Aljazzaf, 2019). Abu Shanab used the personal model and the technical model to predict the level of trust in egovernment in Qatar (Abu Shanab, 2019). Mensah and Adams examined political trust on the adoption of e-government services between foreign and Chinese students (Mensah \& Adams, 2020). Al-Shargabi et al. examined the cloud computing model for building trust in e-government web service in Jordan (Al-Shargabi et al., 2020). Nofal et al. has conducted a study on trust and transparency in the adoption of e-government services by citizens in Jordan (Nofal et al., 2021). Kamarudin et al. predicted that performance expectancy, social influence, and facilitating conditions, and trust influenced the adoption of e-government services in the telecenters in rural areas in Malaysia (Kamarudin et al., 2021).

Scholars have also studied the issue of trust in e-government in Indonesia. Supriyanto et al. developed the design of an inclusive security model on e-government for building public e-government trust on data and information (Supriyanto et al., 2019). Tjen et al. explored the impact of trust, the IS, and prior experience of taxpayers in using online tax filing (e-filing) (Tjen et al., 2019). Assegaff et al. evaluated the factors affecting the trust of millennial citizens in e-government in Jambi, Indonesia. They found that software quality, trust in the internet, reliance on applications influenced the generation behavior (Assegaff et al., 2021).

\section{Trust in E-government}

The meaning of trust is the willingness of one party to obey the wishes and actions of the other party based on expectations (Abu Shanab, 2019). Trust in e-government refers to citizens' confidence that they are protected from fraud, doubt, and harm in using ICTs (Munyoka \& Maharaj, 2019). Trust in e-government is a technology solution presented by government agencies (Ejdys et al., 2019). Trust in e-government is a reciprocal relationship between government agencies that provide public services and the private sector and citizens who expect government employees to be trusted (Bayaga et al., 2020). Trust in e-government is reflected in government-to-citizen relationships, where citizens trust the government to act in a right and fair manner (Pérez-Morote et al., 2020). Trust 
is the main prerequisite for developing the willingness and participation of citizens to use e-government (Khan et al., 2020; Khan et al., 2021).

This study is based on theories that have been developed so far to explain the factors that influence a person's use of e-government. Scholars (Dwivedi et al., 2017; Ospina and Pinzón, 2018; Mustafa et al., 2020) identified a theory of reasoned action (TRA), a technology acceptance model (TAM), a theory of planned behavior (TPB), the diffusion of innovation (DOI), a unified theory of acceptance and use of technology (UTAUT), and a unified model of e-government adoption (UMEGA). Attitude and subjective norm were essential elements in the TRA. The TAM was developed as a TRA adaption to represent users' adoption of IS. The first fundamental component, perceived usefulness, was defined as the subjective likelihood of potential users. Other basic design, such as perceived ease of use, pointed at which the potential user with ease of use of the target gadget. Subjective norm, attitude, and perceived behavioral control were the TPB's conceptions. Attitude, subjective norm, perceived behavioral control, perceived ease of use, perceived usefulness, compatibility, resource enabling conditions, technology facilitating conditions, and selfefficacy were among the constructs studied by the DTPB. Relative advantage, compatibility, image, trial-ability, visibility, ease of use, result, demonstrability, and voluntariness of usage were all constructs of the IDT. Image, perceived utility, perceived ease of use, work relevance, result demonstrability, and subjective norm were all factors in the TAM 2. Compatibility, intricacy, and trial-ability were all advantages for the DOI. Performance expectancy, effort expectancy, social influence, and facilitating factors were all present in the UTAUT. Finally, the UMEGA included performance and effort expectations, as well as social impact, perceived risk, attitude, and facilitating conditions.

\section{Perceived Usefulness and Trust in E-government}

Santhanamery and Ramayah have demonstrated that perceived usefulness influences the link between trust in the system (correctness, response time, system support, availability, and security) and e-filing system usage intention in Malaysia (Santhanamery \& Ramayah, 2018). Aljazzaf evaluated trust in e-government in Kuwait. He found that perceived usefulness affects trust in e-government (Aljazzaf, 2019). Abu Shanab showed predictor variables of perceived usefulness, security and privacy concerns, and information quality and trust in e-government as a dependent variable (Abu Shanab, 2019). Tsui discovered that, in addition to playing a complete mediating function, perceived usefulness is likely to be the most important ex-post factor influencing users' intention to continue using egovernment services in Taiwan (Tsui, 2019). In a study conducted in China, Chen and Komlan discovered that perceived usefulness and perceived ease of use have a substantial impact on behavioral intentions to utilize e-government services (Chen \& Aklikokou, 2020). Uthaman and Vasanthagopal analyzed the mediating effect of perceived ease of use, perceived usefulness, satisfaction, and trust on behavioral intentions of beneficiaries 
to use e-government in India (Uthaman \& Vasanthagopal, 2020). Nofal et al. evaluated e-government adoption in Jordan. They found that the higher the perceived usefulness, the more frequent the adoption of e-government (Nofal et al., 2021).

\section{Information Quality and Trust in E-government}

Information quality, according to Khan et al., refers to citizens' perceptions of the fullness and correctness of e-government information. In Pakistan, they discovered that the higher citizens' perceptions of high-quality information, the more trust they have in e-government (Khan et al., 2021). Losanta et al. designed and developed the local egovernment and information quality to build trust of businessman in using e-government services in Thailand (Losanta \& Deshmukh, 2019). Website quality influenced trust in egovernment (Aljazzaf, 2019). Service quality influenced attitude and intention to use egovernment (Nofal et al., 2021). Kaushik and Mishra examined the effect of perceived information quality and technology anxiety on the e-government adoption process in India (Kaushik \& Mishra, 2019). Abu-Shanab also showed information quality as predictor variable of trust in e-government as dependent variable (Abu Shanab, 2019). Furthermore Rasool et al. assessed that the information quality of websites/portals is vital importance of citizens' use of e-government in Pakistan (Rasool et al., 2019). The National Public Procurement Agency (NPPA) at Indonesian Government Agencies uses the website as a service to citizens to share information related to regulations, organizational profiles, and functions. The quality of information (IQ) on the government websites had become one of the main determinants of user satisfaction (Putri \& Ruldeviyani, 2019). The drivers of continuous use intention for food delivery software applications were investigated using an expanded UTAUT2 model that augments information quality (Lee et al., 2019).

\section{Privacy and Security and Trust in E-government}

Privacy is the right to control private property. The preservation of personal information, avoiding sharing personal information with others, anonymity, secure archiving of personal data, and informed permission are all examples of privacy. Security is a state of being safe. The administrative and technical procedures connected with securing data and information from possible losses, unauthorized access, destruction, use, or disclosure are referred to as security. In the context of e-government, privacy and security relates to information and administrative data (Munyoka \& Maharaj, 2019).

The collection, control, and understanding of information privacy concerns among internet users increased trust of the internet (TOI) and perceived risks, which in turn drove the adoption of e-government in Virginia (Liu \& Carter, 2018). Risk and security were the threats of social networks in e-government in Azerbaijan (Alguliyev et al., 2018). Technological risks, such as security and privacy, as well as performance risk, are seen to 
be major variables that affect trust in e-government (Ejdys et al., 2019). Perceived security and privacy had an effect on trust in e-government in Kuwait (Aljazzaf, 2019). Information quality, perceived usefulness, security, and privacy concerns, as independent variables, affect trust in e-government in Jordanian citizens (Abu Shanab, 2019). Privacy and security affected the continuous use intention e-government services in Korea (Cho et al., 2019). Privacy and security risks were the determinants of e-government services adoption in South Africa (Bayaga et al., 2020). A study validated the effect of organizational privacy assurance on individual privacy concerns, privacy control and risk perception, trustworthiness and non-self-disclosure behavior in Rwanda (Mutimukwe et al., 2020). Perceived privacy influenced trust in using social media for e-government services in Pakistan (Khan et al., 2021).

\section{RESEARCH METHOD Data Collection}

To collect primary data on citizen use of e-government, a survey approach design was devised. As a research tool, this study used a self-managed organized questionnaire to collect primary data. This study examined citizens who access e-government managed by the Department of Communication and Information, Pringsewu Regency, Lampung Province, Indonesia (www.pringsewukab.go.id). This study chose this location with the consideration that this district is less developed so that the government must inform citizens about e-government (Setiawan, n.d.; Oktiani \& Gunawibawa, 2019; Pratiwi et al., 2020).

\section{Sampling Technique}

Simple random sampling, as a form of non-probability sampling, was used in this research. Simple Random Sampling is taking sample members from the population which is done randomly without any pay attention to the existing strata in the population (Sugiyono, 2017). The target respondents of this study were citizens of the regency who using the e-government. This study used the Slovin formula for taking samples with error sampling $10 \%$. Based on information from the government agency, the population was 36,130 between January - August 2020. This study, using the Slovin formula, determined the number of respondents was 100.

\section{Measurement and Analysis Technique}

Quantitative survey questions were used for collecting data. Questionnaires were created using a Likert scale. The respondents' opinions were measured using Likert scales, with 1 indicating strong disagreement, 2 indicating strong disagreement, 3 indicating neutrality, 4 indicating agreement, and 5 indicating strong agreement. Data was analyzed 
by SEM-PLS for the purposes of assessing validity and reliability, as well as testing hypothesis and regression.

\section{Research Model and Hypotheses}

Based on the literature review, the following research model and hypotheses were developed:

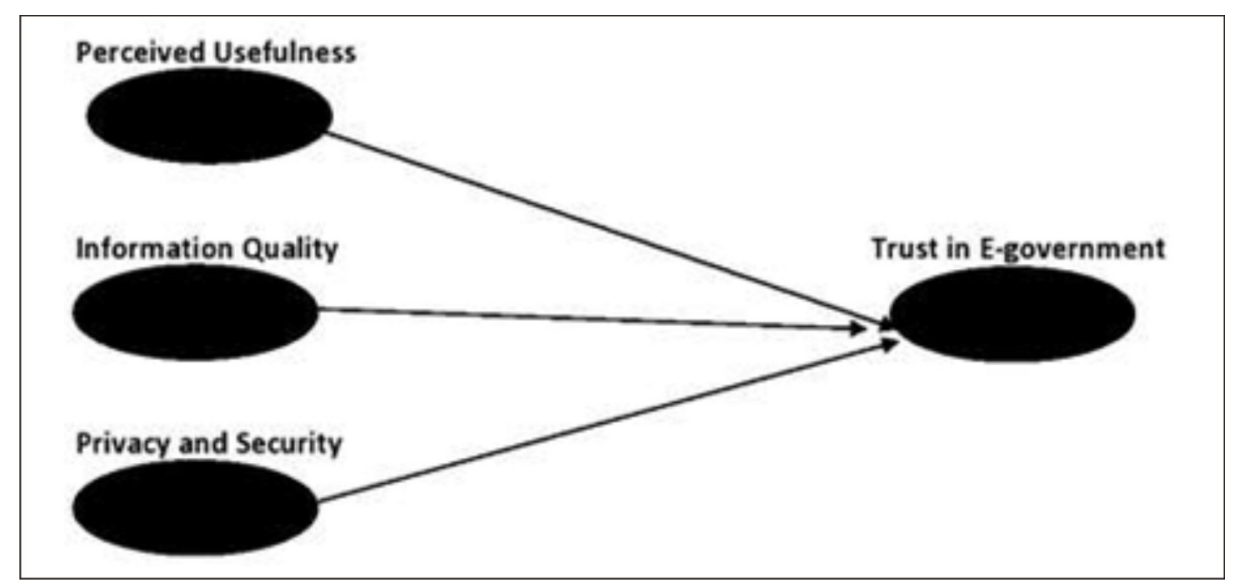

Figure 1. Research model

\section{Hypotheses of This Study}

H1. Perceived usefulness positively and significantly influences citizens trust in egovernment.

H2. Information quality positively and significantly influences citizens trust in egovernment.

H3. Privacy and security positively and significantly influence citizens' trust in egovernment.

The explanation of the above statement is as follows. First, the more positive individual perceived usefulness towards technology, the more intent is to trust in e-government. Second, the more there is an information quality of the ICT, the more positive the individual's trust in e-government will be. Third, the higher the privacy and security of personal data, the more positive citizens' trust in e-government. 


\section{RESULTS}

\section{Demographic Profile of Respondents}

The profile of respondents $(\mathrm{n}=100)$ was as follows: the number of female respondents was $59 \%$ and male was $41 \%$. Respondents who were 20 to 35 years old were $76 \%$, 36 to 51 years old were $22 \%$, and 52 years old and over were $2 \%$. Respondents who have a Diploma or Bachelor's level of education were $54 \%$. The second largest number of respondents who had a junior or senior high school education level were $52 \%$. Finally, the least number of respondents who have a Masters and Doctoral level of education were $4 \%$. The experience of using an electronic-based government system was dominated by users for less than 1 year, i.e. $59 \%$. Users between 1 to 3 years were $27 \%$. Users over 3 years were $13 \%$.

\section{Validated Research Model}

Cronbach's alpha supports internal consistency model measures. When Cronbach's alpha is 0.70 or greater, it means that construct indicators were dependable (Nunnally, 1978). Table 1 shows a high degree of reliability across all variables (perceived usefulness $=0.816$, information quality $=0.798$, privacy and security $=0.919$, and trust in egovernment $=0.741)$.

Tabel 1. Composite Reliability and Cronbach's Alpha

\begin{tabular}{lrcl}
\hline \multicolumn{1}{c}{ Variables } & $\begin{array}{c}\text { Composite } \\
\text { Reliability }\end{array}$ & Cronbach's Alpha & \\
\hline Perceived usefulness & 0.804 & 0.816 & Realibel \\
Information quality & 0.881 & 0.798 & Realibel \\
Privacy and security & 0.920 & 0.919 & Realibel \\
Trust in e-government & 0.746 & 0.741 & Realibel \\
\hline
\end{tabular}

The validity of the indicators that have been established as questionnaires is shown in Figure 2. If the value of an indicator was larger than 0.5, it was considered valid (Chin, 1998). Figure 2 shows that all of the values were greater than 0.5, indicating that all of the indications were valid. 


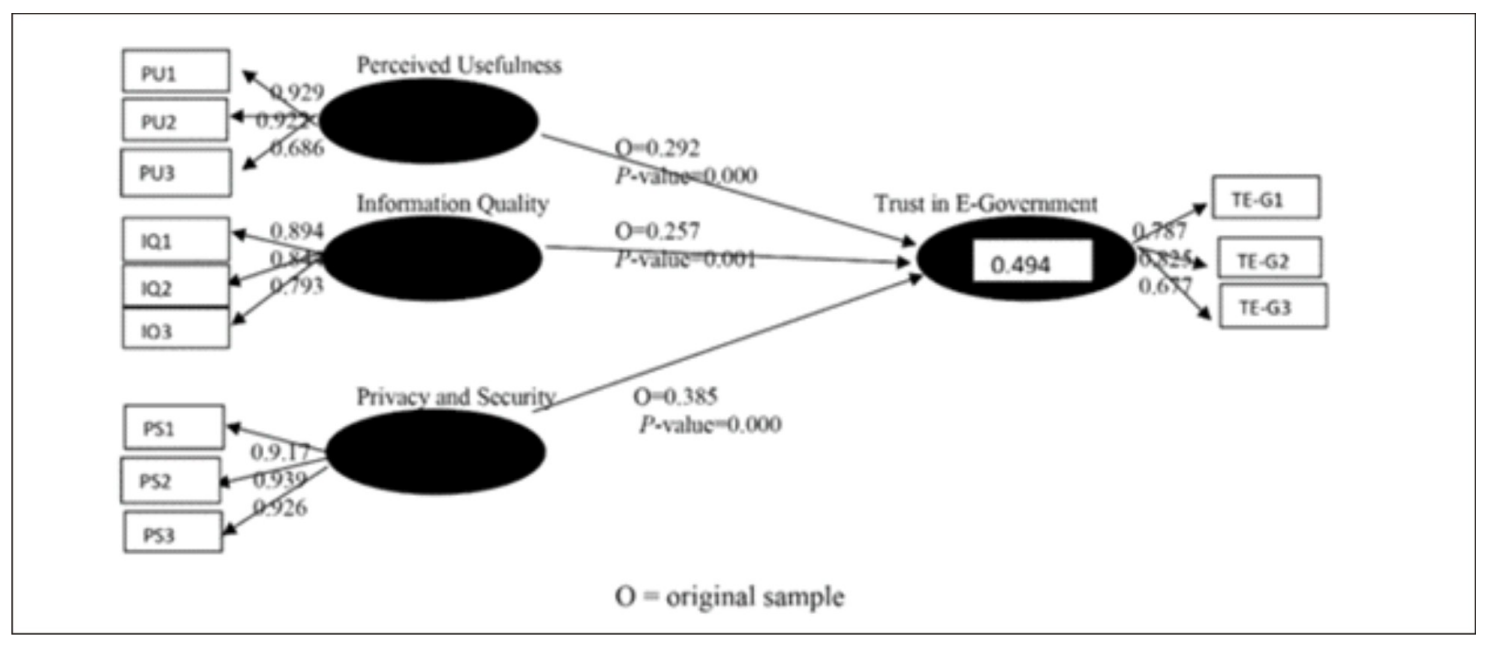

Figure 2. Validated Research Model

The findings of hypothesis testing are also shown in Figure 2. When the p-value was less than 0.05, the hypotheses were accepted (Henseler et al., 2009). As shown in figure 2, the $\mathrm{H} 1$ hypothesis, stating that perceived usefulness positively and significantly influenced trust in e-government, was supported ( $p$-value=0.000). It could be interpreted that the higher the perceived usefulness by users, the more positive the trust in e-government. The $\mathrm{H} 2$ hypothesis, which stated that information quality influenced trust in e-government in a positive and substantial way, was confirmed ( $\mathrm{p}$-value $=0.001$ ). It might be deduced that the higher the website's information quality, the higher the level of trust in e-government. The $\mathrm{H} 3$ hypothesis, which indicated that privacy and security had a positive and significant impact on trust in e-government, was confirmed ( $p$-value $=0.000)$. It is reasonable to conclude that the higher the level of personal data privacy and security, the better the level of trust in e-government.

The original sample shows the strong influence of the independent variable on the dependent variable. Figure 2 shows the effect of perceived usefulness on trust in egovernment is $29.2 \%$. Information quality has a 25.7 percent impact on e-government trust. And the impact of privacy and security on e-government confidence is 38.5 percent.

Regression analysis revealed the degree of influence of the variables, which were categorized into three R-square scales: 19\% - 33\% low (weak), >33\% - 67 percent moderate, and $>67 \%$ strong (substantial) (Chin, 1998). Figure 2 depicts the results of the regression analysis. Trust in e-government was influenced by perceived usefulness, information quality, privacy and security in $49.4 \%$ of cases. It means that independent factors had a moderate amount of control over the dependent variable. 
The critical findings of this study are that the impact of the variables of perceived usefulness and privacy and security is more important than the variable of information quality on trust in e-government in the case in this area. In addition, the effect of the three independent variables on the dependent variable is half of the other independent variables not examined.

This study empirically evaluated variables of perceived usefulness, information quality, and privacy and security in predicting trust in e-government. This study confirmed that perceived usefulness influences trust in e-government ( $p$-value $=0.000$ ) in the case of citizens' using local government website of public services in Indonesia. Therefore, this study justifies some founding of scholars in the difference cases in other countries (Santhanamery \& Ramayah, 2018; Aljazzaf, 2019; Abu Shanab, 2019; Tsui, 2019; Chen \& Aklikokou, 2020; Uthaman \& Vasanthagopal, 2020; Nofal et al., 2021).

In the instance of citizens using local government websites for public services in Indonesia, this study also justified that information quality influences trust in e-government ( $p$-value $=0.001)$. As a result, this research validates the establishment of some scholars in other countries (Khan et al., 2021; Losanta \& Deshmukh, 2019; Aljazzaf, 2019; Nofal et al., 2021; Kaushik \& Mishra, 2019; Abu Shanab, 2019; Rasool et al., 2019; Putri \& Ruldeviyani, 2019; Lee et al., 2019).

This study also proved that privacy and security influences trust in e-government in the case of citizens utilizing local government websites for public services in Indonesia ( $\mathrm{p}$ value $=0.000$ ). As a result, this study supports the work of several experts in other nations (Munyoka \& Maharaj, 2019; Liu \& Carter, 2018; Alguliyev et al., 2018; Ejdys et al., 2019; Aljazzaf, 2019; Abu Shanab, 2019; Cho et al., 2019; Bayaga et al., 2020; Mutimukwe et al., 2020; Khan et al., 2021).

\section{CONCLUSION}

The critical findings of this study are that the impact of the variables of perceived usefulness and privacy and security is more important than the variable of information quality on trust in e-government in the case in this area. In addition, the effect of the three independent variables on the dependent variable is half of the other independent variables not examined. This study empirically evaluated variables of perceived usefulness, information quality, and privacy and security in predicting trust in e-government. This study confirmed that perceived usefulness influences trust in e-government ( $p$-value $=0.000$ ) in the case of citizens' using local government website of public services in Indonesia.

The practical implications are as follows: first, leaders of local government agencies must devise new techniques, such as intense and reinforced socialization of citizens over the perceived utility of the local government's public-services website. Secondly, the 
government agencies encourage employees who manage the local government website to develop privacy and security of data so that citizens increase their trust in government and in the website. Third, local government agencies need to take advantage of the culture of the Indonesian people, such as being obedient, helping, respecting other parties, to build cooperation and trust in e-government. Finally, agencies must transform themselves into more networked and collaborative organizations in order for citizens to have a more positive attitude toward e-government.

This study has limitations and recommendations for future studies. Limitations of this study are that the number of research variables is not large, only one area is used as a case, the number of respondents is not too many, and the research period is relatively short.

Recommendations for further research are as follows. Firstly, future studies could combine the basic constructs with other UTAUT or UMEGA constructs, such as performance and effort expectancy, perceived risk, facilitating condition, and so on. The objective of adding constructs is to see if they are applicable to the case at hand. Furthermore, next studies would include many local government agencies and more citizens to see the consistency of their behavior. Finally, longitudinal data may be used in future studies to validate the performance of the proposed model.

\section{REFERENCES}

Abu Shanab, E. (2019). Predicting Trust in E-government: Two Competing Models. Electronic Government, an International Journal, 15(1), 1-15. https:/ / doi.org/ 10.1504/EG.2019.10015730

Alguliyev, R., Aliguliyev, R., \& Yusifov, F. (2018). Role of Social Networks in E-government: Risks and Security Threats. Online Journal of Communication and Media Technologies, 8(4). https:// doi.org/10.12973/ojcmt/3957

Aljazzaf, Z. M. (2019). Evaluating Trust in E-government: The case of Kuwait. ICCTA '19: 5th International Conference on Computer and Technology Applications, Istanbul, Turkey, April 16 -17, 2019, 140-144. https://doi.org/10.1145/3323933.3324059

Al-Shargabi, B., Al-Jawarneh, S., \& Hayajneh, S. M. A. (2020). A Cloudlet Based Security And Trust Model for E-Government Web Services. Journal of Theoretical and Applied Information Technology, 98(01), 27-37.

Alzahrani, L., Al-Karaghouli, W., \& Weerakkody, V. (2017). Analysing the critical factors influencing trust in e-government adoption from citizens' perspective: A systematic review and a conceptual framework. International Business Review, 26(1), 164-175. https:// doi.org/10.1016/j.ibusrev.2016.06.004

Assegaff, S., Andrianti, A., \& Astri, L. Y. (2021). Evaluation of the Factors Influencing the Trust of Millennial Citizens in E-Government. Journal of Physics: Conference Series, 1898(1), 012009. https://doi.org/10.1088/1742-6596/1898/1/012009 
Bayaga, A., Kyobe, M., \& Ophoff, J. (2020). Criticism of the role of trust in e-government services. 2020 Conference on Information Communications Technology and Society (ICTAS), 1-6. https:/ / doi.org/10.1109/ ICTAS47918.2020.233973

Chen, L., \& Aklikokou, A. K. (2020). Determinants of E-government Adoption: Testing the Mediating Effects of Perceived Usefulness and Perceived Ease of Use. International Journal of Public Administration, 43(10), 850-865. https://doi.org/10.1080/ 01900692.2019.1660989

Chin, W. W. (1998). The partial least squares approach to structural equation modeling. In G. A. Marcoulides (Ed.), Modern Methods for Business Research (pp. 295-358). Lawrence Erlbaum Associates.

Cho, S. H., Oh, S. Y., Rou, H. G., \& Gim, G. Y. (2019). A Study on The Factors Affecting The Continuous Use of E-Government Services-Focused on Privacy and Security Concerns-. 2019 20th IEEE/ACIS International Conference on Software Engineering, Artificial Intelligence, Networking and Parallel/Distributed Computing (SNPD), 351361. https:// doi.org/10.1109/SNPD.2019.8935693

Dias, G. P. (2020). Global e-government development: Besides the relative wealth of countries, do policies matter? Transforming Government: People, Process and Policy, 14(3), 381-400. https:// doi.org/10.1108/TG-12-2019-0125

Dwivedi, Y. K., Rana, N. P., Janssen, M., Lal, B., Williams, M. D., \& Clement, M. (2017). An empirical validation of a unified model of electronic government adoption (UMEGA). Government Information Quarterly, 34(2), 211-230. https://doi.org/ 10.1016/j.giq.2017.03.001

Ejdys, J., Ginevicius, R., Rozsa, Z., \& Janoskova, K. (2019). The Role of Perceived Risk and Security Level in Building Trust in E-government Solutions. Information Management, XXII(3), 220-235. https://doi.org/10.15240/tul/001/2019-3-014

Glyptis, L., Christofi, M., Vrontis, D., Giudice, M. D., Dimitriou, S., \& Michael, P. (2020). E-Government implementation challenges in small countries: The project manager's perspective. Technological Forecasting and Social Change, 152, 119880. https:// doi.org/10.1016/j.techfore.2019.119880

Henseler, J., Ringle, C. M., \& Sinkovics, R. R. (2009). The use of partial least squares path modeling in international marketing. In R. R. Sinkovics \& P. N. Ghauri (Eds.), Advances in International Marketing (Vol. 20, pp. 277-319). Emerald Group Publishing Limited. Horák, J., Bokšová, J., \& Bokša, M. (2021). Implementation of eGovernment from the Perspective of Public Administration. International Advances in Economic Research, 27(1), 87-89. https://doi.org/10.1007/s11294-021-09816-5

Ingrams, A., Manoharan, A., Schmidthuber, L., \& Holzer, M. (2020). Stages and Determinants of E-Government Development: A Twelve-Year Longitudinal Study of Global Cities. International Public Management Journal, 23(6), 731-769. https:// doi.org/10.1080/10967494.2018.1467987 
Kamarudin, S., Omar, S. Z., Zaremohzzabieh, Z., Bolong, J., \& Osman, M. N. (2021). Factors Predicting the Adoption of E-Government Services in Telecenters in Rural Areas: The Mediating Role of Trust. Asia-Pacific Social Science Review, 21(1), 20-38.

Kaushik, K., \& Mishra, R. (2019). Predictors of E-government adoption in India: Direct and indirect effects of technology anxiety and information quality. Int. J. Business Information Systems, 31(3), 305-321.

Khan, S., Rahim, N. Z. Ab., \& Maarop, N. (2020). A systematic literature review and a proposed model on antecedents of trust to use social media for e-government services. International Journal of Advanced and Applied Sciences, 7(2), 44-56. https:/ / doi.org/ 10.21833/ijaas.2020.02.007

Khan, S., Umer, R., Umer, S., \& Naqvi, S. (2021). Antecedents of trust in using social media for E-government services: An empirical study in Pakistan. Technology in Society, 64, 101400. https://doi.org/10.1016/j.techsoc.2020.101400

Lee, S. W., Sung, H. J., \& Jeon, H. M. (2019). Determinants of Continuous Intention on Food Delivery Apps: Extending UTAUT2 with Information Quality. Sustainability, 11(11), 3141. https:// doi.org/10.3390/su11113141

Liu, D., \& Carter, L. (2018). Impact of citizens' privacy concerns on e-government adoption. Proceedings of the 19th Annual International Conference on Digital Government Research: Governance in the Data Age, 1-6. https://doi.org/10.1145/ 3209281.3209340

Liywalii, E., \& Tembo, S. (2019). The Impact of Ethical Issues on E-Government Implementation: A Case of Zambia. International Journal of Information Science, 9(2), 27-39. https:// doi.org/10.5923/j.ijis.20190902.01

Losanta, P. W., \& Deshmukh, S. N. (2019). Design and Development the Framework for Local E- Government and Information Quality in Thailand. International Journal of Scientific Research in Computer Science Applications and Management Studies, 8(2). Mensah, I. K., \& Adams, S. (2020). A Comparative Analysis of the Impact of Political Trust on the Adoption of E-Government Services. International Journal of Public Administration, 43(8), 682-696. https://doi.org/10.1080/01900692.2019.1645687

Mosud, O., \& Govender, I. (2020). Critical issues affecting e-government implementation in Nigeria: A case of housing development agency. African Journal of Gender, Society and Development (Formerly Journal of Gender, Information and Development in Africa), 9(4), 33-58. https://doi.org/10.31920/2634-3622/2020/v9n4a2

Munyoka, W., \& Maharaj, M. S. (2019). Privacy, security, trust, risk and optimism bias in e-government use: The case of two Southern African Development Community countries. South African Journal of Information Management, 21(1), 1-9. https:// doi.org/10.4102/ sajim.v21i1.983 
Mustafa, A., Ibrahim, O., \& Mohammed, F. (2020). E-government adoption: A systematic review in the context of developing nations. International Journal Of Innovation, 8(1), 59-76. https:// doi.org/10.5585/iji.v8i1.343.

Mutimukwe, C., Kolkowska, E., \& Grönlund, Å. (2020). Information privacy in e-service: Effect of organizational privacy assurances on individual privacy concerns, perceptions, trust and self-disclosure behavior. Government Information Quarterly, 37(1), 101413. https:// doi.org/10.1016/j.giq.2019.101413

Nofal, M. I., Al-Adwan, A. S., Yaseen, H., \& Alsheikh, G. A. A. (2021). Factors for extending e-government adoption in Jordan. Periodicals of Engineering and Natural Sciences, 9(2), 471-490.

Nunnally, J. C. (1978). Psychometric Theory. McGraw-Hill.

Oktiani, H., \& Gunawibawa, E. Y. (2019). Tata Kelola Website Desa dan Kapasitas Pengelola dalam Memproduksi Konten sebagai Media Informasi dan Promosi Potensi Desa (Studi pada Pengelolaan dan Kompetensi Pengelola Website Desa di Kecamatan Pringsewu, Kabupaten Pringsewu). Laporan Akhir Penelitian Dasar Universitas Lampung, 1-64.

Ospina, M. L. C., \& Pinzón, B. H. D. (2018). Theoretical Perspectives on Usage of eGovernment Service: A Literature Review. Twenty-Fourth Americas Conference on Information Systems, 1-10.

Panthee, M., \& Sharma, D. Y. K. (2019). Review of E-Government Implementation. International Journal of Recent Research Aspects, 6(1), 26-30.

Pérez-Morote, R., Pontones-Rosa, C., \& Núñez-Chicharro, M. (2020). The effects of egovernment evaluation, trust and the digital divide in the levels of e-government use in European countries. Technological Forecasting and Social Change, 154, 119973. https:// doi.org/10.1016/j.techfore.2020.119973

Pratiwi, R., Saputra, R. H., \& Waziana, W. (2020). Sosialisasi Internet Sehat dan Aman (INSAN). Jurnal PkM Pemberdayaan Masyarakat, 1(2), 27-32.

Putri, M. E., \& Ruldeviyani, Y. (2019). Prioritization Strategy for Government's Website Information Quality: Case Study: Indonesia National Public Procurement Agency. Proceedings of the 2019 International Conference on Information Technology and Computer Communications - ITCC 2019, 37-44. https://doi.org/10.1145/ 3355402.3355409

Rasool, T., Warraich, N. F., \& Rorissa, A. (2019). Citizens' assessment of the information quality of e-government websites in Pakistan. Global Knowledge, Memory and Communication, 69(3), 189-204. https://doi.org/10.1108/GKMC-03-2019-0033

Santhanamery, T., \& Ramayah, T. (2018). Trust in the System: The Mediating Effect of Perceived Usefulness of the E-Filing System. In S. Saeed, T. Ramayah, \& Z. Mahmood (Eds.), User Centric E-Government (pp. 89-103). Springer International Publishing. https://doi.org/10.1007/978-3-319-59442-2_5 
Setiawan, A. (n.d.). E-Government Dalam Rangka Meningkatkan Partisipasi Masyarakat Kabupaten Pringsewu Lampung. Jurusan Sistem Informasi STMIK Pringsewu Lampung, 1-16.

Shkarlet, S., Oliychenko, I., Dubyna, M., Ditkovska, M., \& Zhovtok, V. (2020). Comparative analysis of best practices in e-Government implementation and use of this experience by developing countries. Administratie Si Management Public, 34, 118-136. https:// doi.org/10.24818/amp/2020.34-07

Sugiyono. (2017). Metode Penelitian Kualitatif. Untuk Penelitian yang Bersifat: Eksploratif, Enterpretif, Interaktif, dan Konstruktif. Bandung: Alfabeta

Supriyanto, A., Diartono, D. A., Hartono, B., \& Februariyanti, H. (2019). Inclusive Security Models To Building E-Government Trust. 2019 3rd International Conference on Informatics and Computational Sciences (ICICoS), 1-6. https://doi.org/10.1109/ ICICoS48119.2019.8982457

Tjen, C., Indriani, V., \& Wicaksono, P. T. (2019). Prior Experience, Trust, and IS Success Model: A Study on the Use of Tax E-Filing in Indonesia. Journal of the Australasian Tax Teachers Association, 14(1), 1-24.

Tsui, H.-D. (2019). Trust, Perceived Useful, Attitude and Continuance Intention to Use E-Government Service: An Empirical Study in Taiwan. IEICE Transactions on Information and Systems, E102.D(12), 2524-2534. https://doi.org/10.1587/ transinf.2019EDP7055

Uthaman, Vijaya. S., \& Vasanthagopal, R. (2020). The Mediating Roles of Perceived Ease of Use, Perceived Usefulness, Satisfaction and Trust on Relationship between EGovernance Service Quality and Behavioural Intention: A Study among Beneficiaries of Common Service Centre's in India. 04th International Conference on Marketing, Technology \& Society 2020, 1-4. 